\title{
Effects of Smoking Cessation on Gene Expression in Human Leukocytes of Chronic Smoker
}

\author{
Soo-Jeong Kim¹, Su Young Kim², Jae Hwa Kim¹, and Dai-Jin Kim ${ }^{1}$ \\ 'Department of Psychiatry, Seoul St. Mary's Hospital, The Catholic University of Korea College of Medicine, Seoul, Republic of Korea \\ 2Department of Pathology, Seoul St. Mary's Hospital, The Catholic University of Korea College of Medicine, Seoul, Republic of Korea
}

Objective The risks of cigarette smoking concerning higher systemic disease mortality are lessened by smoking cessation. Methods Microarray analysis compared the expression profiles of smokers who were successful and not successful at smoking cessation, with the goal of identifying genes that might serve as potential biomarkers or that might be valuable in elucidating distinct biological mechanisms. The mRNAs were isolated and compared from peripheral leukocytes of six smokers who were successful in cessation and six smokers who failed in smoking cessation.

Results Two hundred ninety nine genes displayed significantly different expression; 196 genes were up-regulated and 103 genes were down-regulated in the success group compared to the failure group. Twenty four of these genes were identified with biological processes including immunity, cytoskeleton and cell growth/cycle. Real-time PCR confirmed the differential gene expression. The mRNA levels of HEPACAM family member 2 (HEPACAM2) and tropomodulin 1 (TMOD1) were significantly more expressed in the success group, while the mRNA ubiquitin specific peptides 18 (USP18) were significantly less expressed in the success group compared to the failure group.

Conclusion The results suggest that smoking cessation can modulate cell adhesion and immune response by regulating expression levels of genes, especially HEPACAM2, TMOD1 and USP18, which have an important relationship with smoking cessation.

Psychiatry Investig 2014;11(3):290-296

Key Words Nicotine cessation, Microarray, Leucocytes, Real time PCR.

\section{INTRODUCTION}

Cigarette smoke profoundly affects the development and progression of many diseases, including cancers, cardiovascular, chronic obstructive pulmonary and gastrointestinal diseases. ${ }^{1,2}$ Studies addressing the various adverse effects of smoking, including carcinogenic processes, vasomotor dysfunction, impaired endothelial-dependent vasodilatation, and lipid modifications, ${ }^{3}$ have established that smoking cessation is crucially important in lessening and preventing smoking associated preventable diseases and promoting improved public health. Recent studies addressing the effectiveness of smoking cessa-

Received: July 25, 2013 Revised: October 25, 2013

Accepted: October 30, 2013 Available online: July 21, 2014

$\triangle$ Correspondence: Dai-Jin Kim, MD, PhD

Department of Psychiatry, Seoul St. Mary’s Hospital, The Catholic University of Korea College of Medicine, 222 Banpo-daero, Seocho-gu, Seoul 137-701, Republic of Korea

Tel: +82-2-2258-6086, Fax: +82-2-594-3870, E-mail: kdj922@catholic.ac.kr

(c) This is an Open Access article distributed under the terms of the Creative Commons Attribution Non-Commercial License (http://creativecommons.org/licenses/by$\mathrm{nc} / 3.0$ ) which permits unrestricted non-commercial use, distribution, and reproduction in any medium, provided the original work is properly cited. tion have shown that quitting smoking improves the overall life expectancy and lowers the risk of lung cancer, heart attack and stroke. ${ }^{4}$

Cigarette smoke is the principal environmental risk factor. Cigarette smoke negatively influences the immune system, especially interferon induction, apoptosis and xenobiotic metabolism-related gene developments, and is important in neutrophil-derived oxidant injury. ${ }^{5,6}$ Stopping smoking is associated with the elevation in collagenase mRNA expression in human neutrophils, which are crucial in host defense against microorganisms as primary phagocytic cells, and in acute phases of inflammatory reactions. ${ }^{7}$ Although several genes have been linked to the incidence of smoking-related diseases, ${ }^{8}$ little is known of gene expression profiling as an alternative approach to discover positional candidates of benefit to address damage attributed to smoking cessation.

In the present study, microarray analysis clarified the gene expression profiles of peripheral leukocytes from smokers who succeeded or failed in smoking cessation. The differential expression of the selected genes in smokers who were successful 
or unsuccessful in quitting was confirmed using real-time polymerase chain reaction (PCR).

\section{METHODS}

\section{Participants}

Twelve male subjects (mean age $30.4 \pm 6.8$ years) with nicotine dependence defined according to the Diagnostic and Statistical Manual of Mental Disorders, Fourth Edition, Text Revision (DSM-IV-TR) criteria were recruited at Bucheon St. Mary's Hospital, The Catholic University of Korea, by advertisements in the hospital newspaper and on websites. Participants had no mental or physical afflictions, aside from their nicotine dependence. They were not using illegal drugs and any prescribed medications. The participants were instructed not to drink more than five standard alcoholic drinks per week and one cup of coffee per day, and to maintain their eating habits during the smoking cessation to minimize the influence of alcohol, caffeine and change of diet habits on mRNA expression levels.

\section{Smoking cessation}

During the current study, all subjects agreed to quit smoking without taking medication or nicotine replacement therapy. Smoking abstinence was assessed from self-report. Urine cotinine levels were tested by a urinary cotinine immunoassay dipstick (Nicometer; Jant Pharmaceutical, Encino, CA, USA) prior to smoking abstinence and one and two months after smoking abstinence. Success in smoking cessation was validated by a urine cotinine level $<30 \mathrm{ng} / \mathrm{mL}$. All subjects signed an informed consent after receiving a complete description of the study. The study was approved by the Ethics Committee of Bucheon St. Mary's Hospital. The procedures were in accordance with the Helsinki Declaration of 1975, as revised in 1983. Six of the 12 smokers failed to abstain from smoking during the study (failure group), as revealed by the results of urinary tests. The remaining six smokers were successful in smoking abstinence (success group).

\section{RNA preparation}

After two months, fasting peripheral blood of each subject was drawn into an EDTA-coated tube treated with $10 \mu \mathrm{L} / \mathrm{mL}$ of Pefabloc SC (Roche Diagnostics GmbH, Mannheim, Germany). One milliliter of each suspension was mixed with 2 mL of TRIzol LS reagent (Invitrogen, Carlsbad, CA, USA) and total RNA was isolated and purified using the RNeasy mini kit (Qiagen, Valencia, CA, USA). The amount of RNA was determined by measuring the optical density at $260 \mathrm{~nm}\left(\mathrm{OD}_{260}\right)$ with a Nanodrop apparatus (Thermo Scientific, Wilmington, DE, USA) and the quality of the RNA was measured using a model 2100 bioanalyzer (Agilent Technologies, Santa Clara, CA, USA).

\section{Expression profiling}

Two hundred nanograms of each total RNA was used to make Cy3-labeled cRNA using Low Input Quick Amp Labeling Kits (Agilent Technologies). The labeled cRNAs were applied to Custom Gene Expression Microarray, 4x44k (Agilent Technologies) at $65^{\circ} \mathrm{C}$ for 17 hours. After hybridization, the microarrays were washed according to the manufacturer's recommended protocol. Microarray images were acquired using GenePix 4000B (Molecular Devices, Sunnyvale, CA, USA) and the signal intensity of each probe on each microarray was determined using Feature Expression Software (Agilent Technologies). Interarray variation was normalized by quantile normalization. After excluding weak signals $\left(<10^{2.3}\right)$, the remaining 30,398 features were analyzed.

\section{Microarray data analysis}

To reveal differentially expressed genes between the smoking cessation success and failure groups, we calculated shrunken centroids of each group using the pamr package of R. ${ }^{9}$ The maximum number of features showing no misclassification error was selected.

\section{Real-time PCR}

We conducted a RT-PCR to confirm the differential gene expression that selected HEPACAM2, TMOD1, USP18 and IF144 between the success group $(n=6)$ and the failure group $(n=6)$. All oligonucleotide primers were synthesized by Bioneer (Daejeon, Korea) using the following primer sequences: $\beta$-actin-forward primer, TCA CCC ACA CTG TGC CCA TCT ACG A; $\beta$-actin-reverse primer, GGA TGC CAC AGG ATT CCA TAC CCA; HEPACAM2-forward primer, CTG GGG CTG TGG AGT ATG TG; HEPACAM2-reverse primer, CAG GCA GCT GTA ATT CCC AA; TMOD1-forward primer, TGA AGC CAC TGA ACT CTG CC; TMOD1-reverse primer, TTG TTG CCT GGG ATT GGT AA; USP18forward primer, GTC CAT CCT GGC TGA GTC CT; USP18reverse primer, ACC AGG CCA TGA GGG TAG TC; IFI44forward primer, GCA TGT AAC GCA TCA GGC TT; and IFI44-reverse primer, CTC CTT TCT CAC TCA GCC CC. Real-time quantitative RT-PCR was performed in a $25 \mu \mathrm{L}$ total volume containing 20 ng total RNA, $7.5 \mu \mathrm{L}$ RNase Free distilled water, $1 \mu \mathrm{L}$ forward and reverse primers $(10 \mu \mathrm{M}), 1 \mu \mathrm{L}$ PrimeScript 1-step Enzyme Mix 2 and $12.5 \mu \mathrm{L} 2 \mathrm{X}$ One Step SYBR $^{\circledR}$ RT-PCR Buffer 4 (Takara, Kyoto, Japan). The reaction conditions were set at $42^{\circ} \mathrm{C}$ for $5 \mathrm{~min}$ and $95^{\circ} \mathrm{C}$ for $10 \mathrm{sec}$, followed by $40 \mathrm{cycles}$ of $95^{\circ} \mathrm{C}$ for $5 \mathrm{sec}$ and $60^{\circ} \mathrm{C}$ for $30 \mathrm{sec}$. Realtime PCR was carried out using a thermal cycler CFX96 (Bio- 
Rad, Hercules, CA) and triplicate $25 \mu \mathrm{L}$ reactions were performed in Hard-Shell ${ }^{\circledR}$ PCR Plates 96-Well WHT/WHT (BioRad).

\section{Comparative calculation}

The results of real-time PCR data are shown as Ct values, which are defined as the number of cycles required for the fluorescent signal to cross a threshold and which are inversely proportional to the amount of target cDNA in the sample. The $\Delta \mathrm{Ct}$ value was calculated by subtracting the $\mathrm{Ct}$ of control ( $\beta$-actin) from the $\mathrm{Ct}$ of target gene (HEPACAM2, TMOD1, USP18 and IFI44); $\Delta \Delta \mathrm{Ct}$ represented the different expression of each sample, according to mean expression of the success group, as calculated by the formula $\Delta \Delta \mathrm{Ct}=\Delta \mathrm{Ct}$-mean $\Delta \mathrm{Ct}$ of the success group. The $\mathrm{N}$-fold differential expression in a specific gene of a sample was expressed as $2^{\wedge}(-\Delta \Delta \mathrm{Ct})$.

\section{Statistical analysis}

The comparison of the $\mathrm{N}$-fold gene expression between the two groups, was performed by a two-tailed Students' ttest. The analysis was done using the Statistical Package for the Social Sciences (SPSS) version 18.0 for Windows. We considered $\mathrm{p}<0.05$ to be statistically significant.

\section{RESULTS}

\section{Expression profiles}

We identified 299 features with no misclassification error using the pamr module of R (9). Hierarchical clustering based on the 299 features clearly divided the samples into two clusters; success vs. failure groups (Figure 1). However, individual differences hindered the finding of any common time-course change in each group. Of these 299 genes, 196 were up-regu- lated and 103 were down-regulated in the success group, compared to that of the failure group, and 24 genes were classified into biologically relevant categories according to their functions (Table 1).

\section{Real-time PCR}

To confirm the expression levels obtained by the microarrays, relative quantitative real-time RT-PCR was performed for four selected genes: HEPACAM2, TMOD1, USP18 and IFI44 (Figure 2). Significantly higher expressions of HEPACAM2 $(\mathrm{p}=0.024)$ and TMOD1 $(\mathrm{p}<0.001)$ were evident, as was the reduced expression of USP18 ( $\mathrm{p}=0.033)$ in the success group compared to the failure group. IFI44 expression was reduced in the success group, but the decrease was not significant.

\section{DISCUSSION}

The present study used the microarray technique to explore the expression levels of genes as a way of assessing the effectiveness of smoking cessation in the peripheral leukocytes of the success group and the failure group. Expression of 299 genes differed between the two groups, and 24 genes were classified into several functional groups.

The first group included the genes involved in immunity and anti-immunity. APOBEC3A, CD55 were up-regulated and ITGB7, KIR2DS2, TNFRSF17, IFIT1, IFI44, IFI6, USP18, and HERC5 were down-regulated in the success group. The biological effects of cigarette smoking cessation on the immune system are unclear. Smoking stimulates the oxidative burst, which has a potential role in disease progression by suppression of neutrophil responses induced by subgingival plaque/ bacterial products and immune complexes disease sites. ${ }^{10,11} \mathrm{It}$ is also involved in synthesis and secretion of immunoregulato-

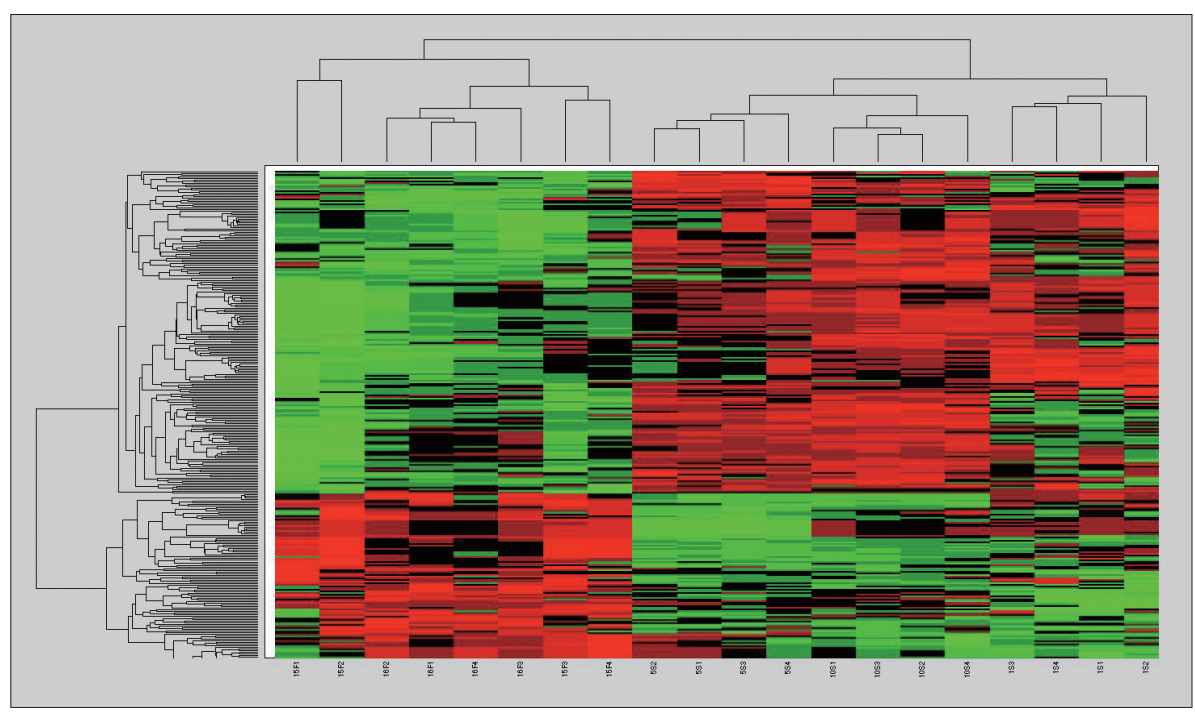

Figure 1. Hierarchical clustering of 299 differentially expressed genes in chronic smokers. 
Table 1. Gene expression patterns of selective genes in the success group and the failure group

\begin{tabular}{|c|c|c|c|c|c|}
\hline \multirow{2}{*}{ Category } & \multirow{2}{*}{ Symbol } & \multirow{2}{*}{ Gene name } & \multicolumn{3}{|c|}{ Median expression of } \\
\hline & & & Success (S) & Failure (F) & Ratio of $S / F$ \\
\hline \multirow[t]{8}{*}{$\begin{array}{l}\text { Immunity/ } \\
\text { Anti-immunity }\end{array}$} & APOBEC3A & $\begin{array}{l}\text { Apolipoprotein B mRNA editing enzyme, } \\
\text { catalytic polypeptide-like } 3 \mathrm{~A}\end{array}$ & 3.76 & 2.84 & 1.32 \\
\hline & CD55 & $\begin{array}{l}\text { CD55 molecule, decay accelerating factor } \\
\text { for complement }\end{array}$ & 3.39 & 3.15 & 1.08 \\
\hline & ITGB7 & Integrin, beta 7 & 4.05 & 4.25 & 0.95 \\
\hline & KIR2DS2 & $\begin{array}{l}\text { Killer cell immunoglobulin-like receptor, } \\
\text { two domains, short cytoplasmic tail, } 2\end{array}$ & 2.55 & 2.80 & 0.91 \\
\hline & TNFRSF17 & $\begin{array}{l}\text { Tumor necrosis factor receptor } \\
\text { superfamily, member } 17\end{array}$ & 2.35 & 2.68 & 0.88 \\
\hline & IFIT1 & $\begin{array}{l}\text { Interferon-induced protein with } \\
\text { tetratricopeptide repeats } 1\end{array}$ & 3.82 & 4.71 & 0.81 \\
\hline & USP18 & Ubiquitin specific peptidase 18 & 2.48 & 3.18 & 0.78 \\
\hline & HERC5 & Hect domain and RLD 5 & 2.64 & 3.61 & 0.73 \\
\hline \multirow[t]{4}{*}{ Cytoskeleton } & TMOD1 & Tropomodulin 1 & 3.06 & 2.60 & 1.18 \\
\hline & ЕРB49 & Erythrocyte membrane protein band 4.9 & 3.32 & 3.05 & 1.09 \\
\hline & ANK1 & Ankyrin 1, erythrocytic & 3.34 & 3.21 & 1.04 \\
\hline & EPB41 & Erythrocyte membrane protein band 4.1 & 2.64 & 2.53 & 1.04 \\
\hline \multirow[t]{4}{*}{ Cell growth/Cycle } & MAPK3 & Mitogen-activated protein kinase 3 & 2.80 & 2.50 & 1.12 \\
\hline & CCNG2 & Cyclin G2 & 2.34 & 2.10 & 1.11 \\
\hline & ANXA3 & Annexin A3 & 3.23 & 3.08 & 1.05 \\
\hline & IFI44 & Interferon-induced protein 44 & 3.46 & 4.32 & 0.80 \\
\hline \multicolumn{6}{|l|}{ Unclassified } \\
\hline Antioxidant & GSTT1 & Glutathione S-transferase theta 1 & 1.99 & 1.66 & 1.20 \\
\hline Calcium homeostasis & NUCB1 & Nucleobindin 1 & 2.69 & 2.54 & 1.06 \\
\hline Cancer-related & MXRA7 & Matrix-remodelling associated 7 & 3.46 & 3.66 & 0.95 \\
\hline Chaperone & AHSP & Alpha hemoglobin stabilizing protein & 4.13 & 3.99 & 1.03 \\
\hline Development & GRHL1 & Grainyhead-like 1 & 2.38 & 2.18 & 1.09 \\
\hline Digestion & MGAM & Maltase-glucoamylase & 2.88 & 2.63 & 1.09 \\
\hline $\begin{array}{l}\text { Protects against } \\
\text { mitochondrial dysfunction }\end{array}$ & PINK1 & PTEN induced putative kinase 1 & 3.80 & 3.44 & 1.10 \\
\hline Cell adhesion & HEPACAM2 & HEPACAM family member 2 & 2.40 & 2.02 & 1.18 \\
\hline
\end{tabular}

CD55: Complement decay-accelerating factor molecule, HERC5: Hect domain and RCC1-like domain-containing protein 5, PINK1: Phosphatase and tensin homolog-induced putative kinase 1, HEPACAM2: Herpa cell adhesion molecule family member 2

ry cytokines and inflammatory mediators, and may reduce neutrophil chemotaxis that indicates alterations in the morphology and adhesion property of neurophils, which reduces functional capacity. ${ }^{12}$ APOBEC3A prevents virus infections by providing intracellular resistance to retrovirus replication and transposition of endogenous retroelements. ${ }^{13}$ The CD55 regulatory protein of the complement cascade inhibits the net increase in complement-mediated cytotoxicity by the alternative pathway. ${ }^{14}$ ITGB plays a critical role in the mucosal immunity and is linked to inflammatory bowel disease. ${ }^{15}$ Additionally, KIR2DS2 influences natural killer cell activating, which promotes cell lysis and absence of KIR2DS2, and is associated with resistance to inflammatory bowel disease. ${ }^{16}$ TNFRSF17 might contribute to the progression of multiple myeloma ${ }^{17}$ and IFIT1 is a potential diagnostic marker for myelodysplasia and systemic lupus. ${ }^{18}$ Inflammatory-stimuli-dependent gene, HERC5, is up-regulated by tumor necrosis factor-alpha or lipopolysaccharide stimulation in late inflammation phase. ${ }^{19}$ Several studies reported that cigarette smoking adversely affects the immune system, particularly lymphocyte development, and strongly correlates with inflammation markers. ${ }^{20,21}$ However, smoking cessation restores the immune levels to normal and lowers airway inflammation, and the degree of improvement is better when using the anti-inflammatory treatment. ${ }^{20,22}$ Ex- 

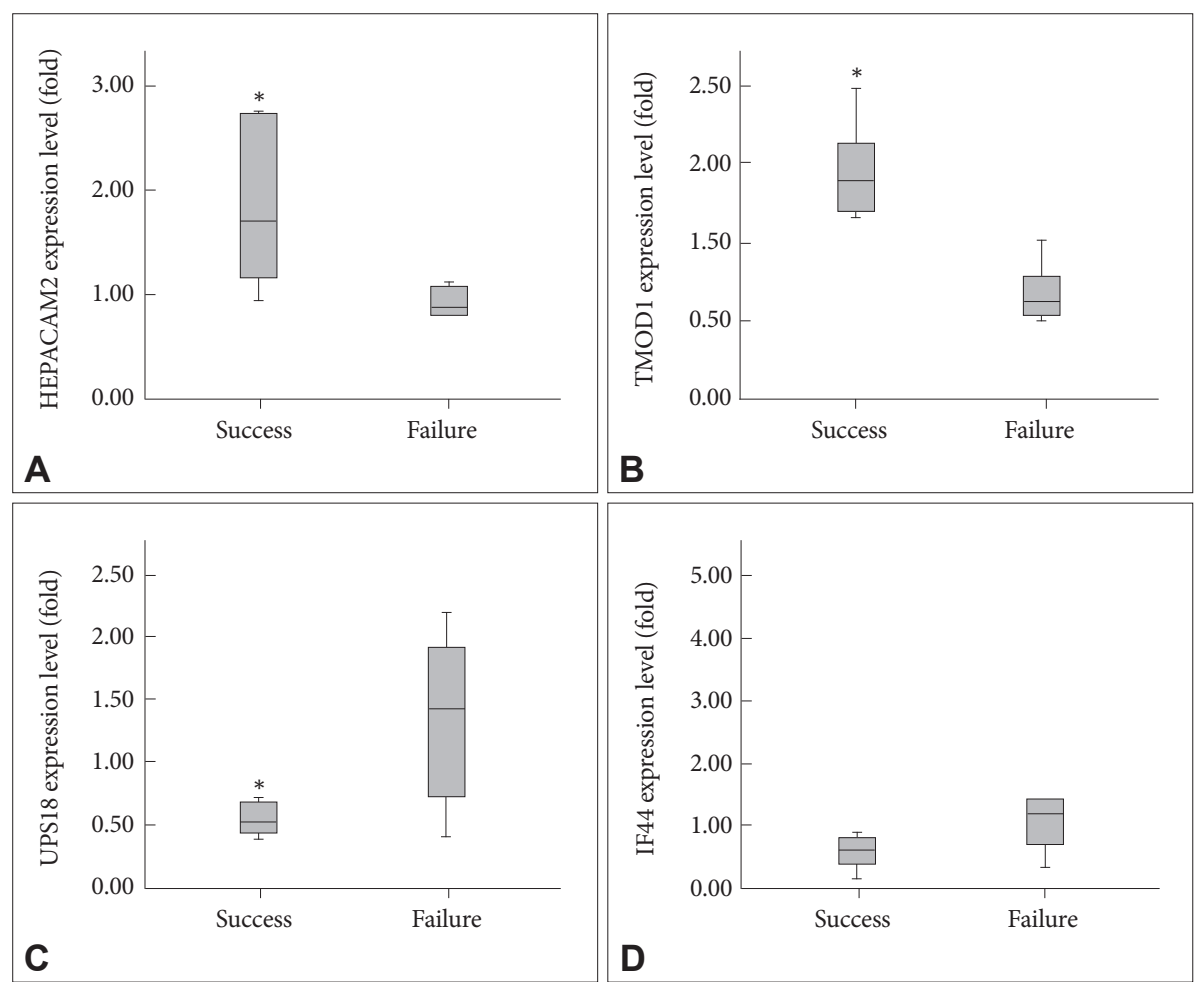

Figure 2. Quantitative analysis of the mRNA expression levels relative to beta-actin between the success group and the failure group (mean $\pm S D$ ). Graphs A-D show the gene expression levels of A: herpa cell adhesion molecule 2, B: Tropomodulin 1, C: Ubiquitin specific peptidase 18, D: Interferon-induced protein 44. *indicates statistical significance $(p<$ 0.05).

trapolating from our results, smoking cessation could decrease the inflammation, protect humans from the development of infections and, overall, may strengthen immunity. Moreover, changes in the expression of immune-related genes might participate in the improvement of immunity.

The second group was cytoskeleton-related genes, which include TMOD1, EPB49, ANK1 and EPB41. All these genes were more highly expressed in the success group. Cigarette smoking has been linked to impairment of cytoskeletal integrity and endothelial organization. ${ }^{23,24}$ EPB49 is an actin-binding and bundling protein of the erythroid membrane skeleton, and is abundantly expressed in the human brain, heart, skeletal muscle and the lung, ${ }^{25}$ thus, it supports the erythrocyte membrane. Also, ANK1 is a major protein of the erythrocyte membrane skeleton that forms the link between the membrane and the underlying spectrin cytoskeleton. ${ }^{26}$ In addition, EBP41, as an essential component of the spectrin-based membrane skeleton, ${ }^{27}$ it plays a key role in determining the morphological and mechanical properties of red cells. Consequently, it is reasonable to speculate that improved the membrane regulates physical properties of the mechanical stability, and deformability after smoking cessation, especially in red blood cells.

Finally, cell cycle and growth-related genes were classified as the third group, which contained MAPK3, CCNG2, ANXA3 and IFI44. MAPK3, CCNG2 and ANXA3 were up-regulated and IFI44 was down-regulated in the success group. MAPK3 induces cell proliferation or differentiation, such as in the neuronal regeneration, after injury and acts in whole-body development. ${ }^{28}$ CCNG2 might promote cell cycle progression, and is significantly down-regulated in oral cancer epithelia. ${ }^{29} \mathrm{~A}$ recent study reported ANXA3 acts as a positive regulator on hepatocyte growth ${ }^{30}$ and decreased IFI44 expression levels probably allow normal cell growth. ${ }^{31}$ Previous cell studies have concluded that cigarette smoking has negative effects on cytotrophoblast progression through the cell cycle and prevents cell growth by inducing significant cytotoxicity. ${ }^{32,33}$ Our results supported these previously described outcomes. Furthermore, our findings indicate that, during smoking cessation, cell proliferation and development will increase due to cellular compensation. Although genes involved in mediating smoking cessation may still be unknown or functionally uncharacterized, they may also have a role in reduced preventable diseases caused by smoking.

We validated the microarray results obtained with some representative genes considered as a highlight potential biomarkers that are participate in different cellular and physiological functions in a smoking cessation. The 4 genes, i.e., HEPACAM2, TMOD1, USP18 and IFI44 were selected because they might reduce preventable diseases caused by smoking and manage specific physiological activates related to smoking cessation. The mRNA expression levels of HEPACAM2 and TMOD were up-regulated and USP18 was down-regulated in the success group. HEPACAM2 mediates cell-extracellular matrix and cell-cell interactions, which are critical for the formation and maintenance of cellular architecture, but also for normal biological processes, which includes the regulation of cellular 
adhesion, proliferation, apoptosis, migration and differentiation. ${ }^{34}$ Moreover, its expression is frequently silenced in a variety of tumor types, because disruption of normal cell adhesion in the transformed cells may contribute to the enhanced migration and proliferation of tumor cells, leading to invasion and metastasis. ${ }^{34,35}$ In addition, TMOD1 is a highly conserved capping protein of the pointed ends of the sarcomeric actin filaments and erythrocyte membrane, and is involved in the architecture of the sarcomere in muscle cells and the membrane skeleton in the non-muscle cells. ${ }^{36}$ TMOD1-null mice exhibit a mild anemia with features that resemble hereditary spherocytic elliptocytosis, failure of myofibril assembly and aborted cardiac development. ${ }^{37,38}$ The current results support the suggestion that USP18 might be linked to the innate immune response to viruses and USP18 gene down-regulation, which results in an increased antiviral activity against many kinds of viruses. ${ }^{39}$ Interestingly, USP18 probably has oncogenic properties, and its inhibition may have possibilities for cancer therapeutics. ${ }^{40}$ Cohort studies have indicated that prevention and cessation of smoking are the most important determinants of lung, head and neck cancer. ${ }^{41,42}$ Hence, it can be assumed that the effects of the increased expression of the HEPACAM2 and TMOD1 genes, and the lowered USP18 gene expression resulting from smoking cessation affects the red blood cell membrane and antiviral ability. This may also be associated with reduced risk of cigarette smoking-related diseases, especially cancers.

To the best of our knowledge, this is the first study about the effectiveness of smoking cessation on gene expression of smokers, while further studies are required to delineate the biological response involved in intervention of impairment caused by cigarette smoking and development of systemic diseases. This microarray analysis demonstrates that smoking cessation of heavy smokers represented the changes in the expression of at least 299 genes in the circulating blood, and indicates that smoking cessation alters the gene expression that is related to immunity, cytoskeleton, cell adhesion, cell proliferation and cancer. The present data provides insights into smoking cessation-related pathological processes by determining its influences at the gene expression level. Gene profiles obtained from these results, therefore, could serve as available information regarding the beneficial effects of smoking cessation and help elucidate the specific mechanisms that mediate the host response to cigarette smoke exposure.

\section{Acknowledgments}

This study was supported by a grant of the Korea Health 21 R\&D Project, Ministry for Health, Welfare and Family Affairs, Republic of Korea (A090058).

\section{REFERENCES}

1. Mayer AS, Newman LS. Genetic and environmental modulation of chronic obstructive pulmonary disease. Respir Physiol 2001;128:3-11.

2. Eriksen MP, LeMaistre CA, Newell GR. Health hazards of passive smoking. Annu Rev Public Health 1988;9:47-70.

3. Celermajer DS, Sorensen KE, Georgakopoulos D, Bull C, Thomas O, Robinson J, et al. Cigarette smoking is associated with dose-related and potentially reversible impairment of endothelium-dependent dilation in healthy young adults. Circulation 1993;88:2149-2155.

4. Mulcahy R. The health benefits of smoking cessation. Ir Med J 1990; 83:45-46.

5. Charles PC, Alder BD, Hilliard EG, Schisler JC, Lineberger RE, Parker JS, et al. Tobacco use induces anti-apoptotic, proliferative patterns of gene expression in circulating leukocytes of Caucasian males. BMC Med Genomics 2008;1:38.

6. Chapple IL, Matthews JB. The role of reactive oxygen and antioxidant species in periodontal tissue destruction. Periodontol 2000 2007;43:160232 .

7. Morozumi T, Kubota T, Sugita N, Itagaki M, Yoshie H. Alterations of gene expression in human neutrophils induced by smoking cessation. J Clin Periodontol 2004;31:1110-1116.

8. Quaak M, van Schayck CP, Knaapen AM, van Schooten FJ. Genetic variation as a predictor of smoking cessation success. A promising preventive and intervention tool for chronic respiratory diseases? Eur Respir J 2009;33:468-480.

9. Tibshirani R, Hastie T, Narasimhan B, Chu G. Diagnosis of multiple cancer types by shrunken centroids of gene expression. Proc Natl Acad Sci U S A 2002;99:6567-6572.

10. Matthews JB, Chen FM, Milward MR, Ling MR, Chapple IL. Neutrophil superoxide production in the presence of cigarette smoke extract, nicotine and cotinine. J Clin Periodontol 2012;39:626-634.

11. Ryder MI, Fujitaki R, Johnson G, Hyun W. Alterations of neutrophil oxidative burst by in vitro smoke exposure: implications for oral and systemic diseases. Ann Periodontol 1998;3:76-87.

12. Van Dyke TE, Wilson-Burrows C, Offenbacher S, Henson P. Association of an abnormality of neutrophil chemotaxis in human periodontal disease with a cell surface protein. Infect Immun 1987;55:2262-2267.

13. Harris RS, Liddament MT. Retroviral restriction by APOBEC proteins. Nat Rev Immunol 2004;4:868-877.

14. Golay J, Zaffaroni L, Vaccari T, Lazzari M, Borleri GM, Bernasconi S, et al. Biologic response of B lymphoma cells to anti-CD20 monoclonal antibody rituximab in vitro: CD55 and CD59 regulate complementmediated cell lysis. Blood 2000;95:3900-3908.

15. van Heel DA, Satsangi J, Carey AH, Jewell DP. Inflammatory bowel disease: progress toward a gene. Can J Gastroenterol 2000;14:207-218.

16. Estefania E, Gomez-Lozano N, Portero F, de Pablo R, Solis R, Sepulveda S, et al. Influence of KIR gene diversity on the course of HSV-1 infection: resistance to the disease is associated with the absence of KIR2DL2 and KIR2DS2. Tissue Antigens 2007;70:34-41.

17. Zhao C, Inoue J, Imoto I, Otsuki T, Iida S, Ueda R, et al. POU2AF1, an amplification target at 11q23, promotes growth of multiple myeloma cells by directly regulating expression of a B-cell maturation factor, TNFRSF17. Oncogene 2008;27:63-75.

18. Ye S, Pang H, Gu YY, Hua J, Chen XG, Bao CD, et al. Protein interaction for an interferon-inducible systemic lupus associated gene, IFIT1. Rheumatology (Oxford) 2003;42:1155-1163.

19. Kroismayr R, Baranyi U, Stehlik C, Dorfleutner A, Binder BR, Lipp J. HERC5, a HECT E3 ubiquitin ligase tightly regulated in LPS activated endothelial cells. J Cell Sci 2004;117:4749-4756.

20. Mili F, Flanders WD, Boring JR, Annest JL, Destefano F. The associations of race, cigarette smoking, and smoking cessation to measures of the immune system in middle-aged men. Clin Immunol Immunopathol 1991;59:187-200.

21. Frohlich M, Sund M, Lowel H, Imhof A, Hoffmeister A, Koenig W. In- 
dependent association of various smoking characteristics with markers of systemic inflammation in men. Results from a representative sample of the general population (MONICA Augsburg Survey 1994/95). Euro Heart J 2003;24:1365-1372.

22. Chaudhuri R, Livingston E, McMahon AD, Lafferty J, Fraser I, Spears $M$, et al. Effects of smoking cessation on lung function and airway inflammation in smokers with asthma. Am J Respir Crit Care Med 2006; 174:127-133.

23. Bernhard D, Csordas A, Henderson B, Rossmann A, Kind M, Wick G. Cigarette smoke metal-catalyzed protein oxidation leads to vascular endothelial cell contraction by depolymerization of microtubules. FASEB J 2005;19:1096-1107.

24. Ambrose JA, Barua RS. The pathophysiology of cigarette smoking and cardiovascular disease: an update. J Am Col Cardiol 2004;43:1731-1737.

25. Azim AC, Knoll JH, Beggs AH, Chishti AH. Isoform cloning, actin binding, and chromosomal localization of human erythroid dematin, a member of the villin superfamily. J Biol Chem 1995;270:17407-17413.

26. Miraglia del Giudice E, Francese M, Nobili B, Morle L, Cutillo S, Delaunay J, et al. High frequency of de novo mutations in ankyrin gene (ANK1) in children with hereditary spherocytosis. J Pediatr 1998;132: 117-120.

27. Parra M, Gee S, Chan N, Ryaboy D, Dubchak I, Mohandas N, et al. Differential domain evolution and complex RNA processing in a family of paralogous EPB41 (protein 4.1) genes facilitate expression of diverse tissue-specific isoforms. Genomics 2004;84:637-646.

28. Kitahara T, Kiryu S, Ohno K, Morita N, Kubo T, Kiyama H. Up-regulation of ERK (MAP kinase) and MEK (MAP kinase kinase) transcription after rat facial nerve transection. Neurosci Res 1994;20:275-280.

29. Kim Y, Shintani S, Kohno Y, Zhang R, Wong DT. Cyclin G2 dysregulation in human oral cancer. Cancer Res 2004;64:8980-8986.

30. Niimi S, Harashima M, Gamou M, Hyuga M, Seki T, Ariga T, et al. Expression of annexin $\mathrm{A} 3$ in primary cultured parenchymal rat hepatocytes and inhibition of DNA synthesis by suppression of annexin A3 expression using RNA interference. Biol Pharm Bull 2005;28:424-428.

31. Hallen LC, Burki Y, Ebeling M, Broger C, Siegrist F, Oroszlan-Szovik $\mathrm{K}$, et al. Antiproliferative activity of the human IFN-alpha-inducible protein IFI44. J Interferon Cytokine Res 2007;27:675-680.

32. Genbacev O, McMaster MT, Lazic J, Nedeljkovic S, Cvetkovic M, Joslin $\mathrm{R}$, et al. Concordant in situ and in vitro data show that maternal cigarette smoking negatively regulates placental cytotrophoblast passage through the cell cycle. Reprod Toxicol 2000;14:495-506.

33. Gocze PM, Freeman DA. Cytotoxic effects of cigarette smoke alkaloids inhibit the progesterone production and cell growth of cultured MA-10 Leydig tumor cells. Euro J Obstet Gynecol Reprod Biol 2000;93:77-83.

34. He Y, Wu X, Luo C, Wang L, Lin J. Functional significance of the hepaCAM gene in bladder cancer. BMC Cancer 2010;10:83.

35. Moh MC, Zhang T, Lee LH, Shen S. Expression of hepaCAM is downregulated in cancers and induces senescence-like growth arrest via a p53/p21-dependent pathway in human breast cancer cells. Carcinogenesis 2008;29:2298-2305.

36. Fischer RS, Fowler VM. Tropomodulins: life at the slow end. Trends Cell Biol 2003;13:593-601.

37. Moyer JD, Nowak RB, Kim NE, Larkin SK, Peters LL, Hartwig J, et al. Tropomodulin 1-null mice have a mild spherocytic elliptocytosis with appearance of tropomodulin 3 in red blood cells and disruption of the membrane skeleton. Blood 2010;116:2590-2599.

38. Fritz-Six KL, Cox PR, Fischer RS, Xu B, Gregorio CC, Zoghbi HY, et al. Aberrant myofibril assembly in tropomodulin1 null mice leads to aborted heart development and embryonic lethality. The J Cell Biol 2003;163:1033-1044.

39. Ritchie KJ, Hahn CS, Kim KI, Yan M, Rosario D, Li L, et al. Role of ISG15 protease UBP43 (USP18) in innate immunity to viral infection. Nat Med 2004;10:1374-1378.

40. Duex JE, Comeau L, Sorkin A, Purow B, Kefas B. Usp18 regulates epidermal growth factor (EGF) receptor expression and cancer cell survival via microRNA-7. J Biol Chem 2011;286:25377-25386.

41. Gritz ER, Carr CR, Rapkin D, Abemayor E, Chang LJ, Wong WK, et al. Predictors of long-term smoking cessation in head and neck cancer patients. Cancer Epidemiol Biomarkers Prev1993;2:261-270.

42. Ebbert JO, Yang P, Vachon CM, Vierkant RA, Cerhan JR, Folsom AR, et al. Lung cancer risk reduction after smoking cessation: observations from a prospective cohort of women. J Clin Oncol 2003;21:921-926. 